\title{
Surfaces
}

\section{GESTURING TOWARD THE VISUAL: VIRTUAL REALITY, HYPERTEXT AND EMBODIED FEMINIST CRITICISM}

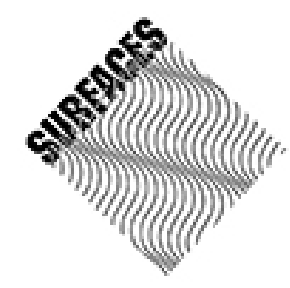

\section{Carolyn Guertin}

Volume 8, 1999

HUMANITÉS ET INFORMATIQUE : QUI A LES COMMANDES?

HUMANITIES AND COMPUTING: WHO'S DRIVING?

URI : https://id.erudit.org/iderudit/1065074ar

DOI : https://doi.org/10.7202/1065074ar

Aller au sommaire du numéro

Éditeur(s)

Les Presses de l’Université de Montréal

ISSN

1188-2492 (imprimé)

1200-5320 (numérique)

Découvrir la revue

Citer cet article

Guertin, C. (1999). GESTURING TOWARD THE VISUAL: VIRTUAL REALITY, HYPERTEXT AND EMBODIED FEMINIST CRITICISM. Surfaces, 8.

https://doi.org/10.7202/1065074ar
Résumé de l'article

Les critiques féministes ont au moins autant tardé que l'ensemble du milieu universitaire à reconnaître la légitimité de la communication électronique de travaux critiques. Cependant, on trouve chez les féministes issues du milieu des lettres et des arts une plus grande sensibilité à la philosophie, si ce n'est toujours au médium, des possibilités ouvertes par l'informatique. Le potentiel pour le développement d'une critique féministe hypertextuelle d'avant-garde est étudiée à la lumière de la mise en scène de la réalité virtuelle que propose Nicole Brossard dans son roman Baroque d'aube et du travail de l'artiste Catherine Richards intitulé The Virtual Body and Curiosity Cabinet, at the End of the Millennium. 


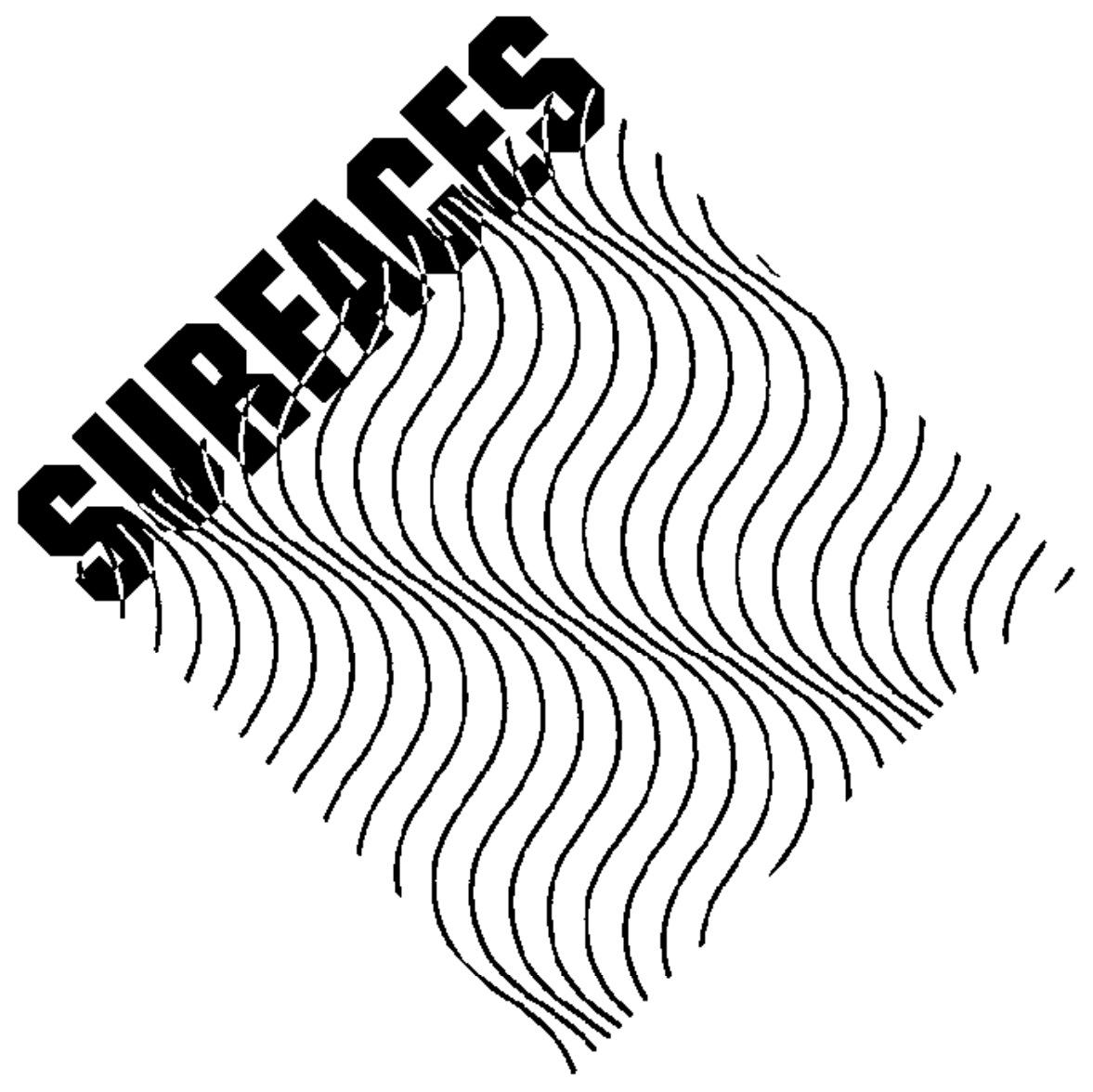

GESTURING TOWARD THE VISUAL

VIRTUAL REALITY, HYPERTEXT AND EMBODIED FEMINIST CRITICISM

Carolyn Guertin 


\section{Rédacteur en chef:}

Jean-Claude Guédon

\section{Comité fondateur:}

Wlad Godzich

Walter Moser

Michel Pierssens
Christie McDonald

Antonio Gómez-Moriana

Gilles Bibeau

\section{Remerciements:}

SURFACES peut paraître grâce à un soutien des Presses de l'Université de Montréal, ainsi qu'à une aide matérielle importante (locaux, mobilier, services informatiques) de l'Université de Montréal.

\section{Adresses:}

\section{SURFACES}

Département de littérature comparée Université de Montréal C.P. 6128, succ. Centre-ville Montréal, Qc, Canada H3C 3J7

Tél.: (514) 3435683

Fax: (514) 3435684

Accès sur INTERNET www.pum.umontreal.ca/revues/surfaces

Assistance technique et questions éditoriales: guedon@ere.umontreal.ca

ISSN: $1188-2492$ 


\section{Soumission des textes}

Vous pouvez soumettre vos articles, revues, notes, commentaires ou autres aux éditeurs par courrier électronique, par disquette ou par lettre. En ce qui concerne les notes bibliographiques, veuillez suivre le protocole du MLA. Nous vous demandons également de joindre à votre texte un court résumé de 3 à 4 lignes.

Tout article publié que l'auteur voudra modifier ultérieurement sera de nouveau évalué. Si accepté, il se substituera à la première version avec une nouvelle date et la mention v. 2.

Tout texte reste la propriété de son auteur. Néanmoins, SURFACES demande d'être citée à l'occasion de toute autre publication du texte en question.

\section{Citation des textes}

Pour toute citation, veuillez consulter le document source afin d'obtenir la dernière version du texte qui vous intéresse et vous baser sur la pagination flottante (/pp. $\mathrm{xx} /$ ) plutôt que sur la foliation (pied de page). Si vous n'avez pas accès au courrier électronique, adressez-vous aux éditeurs qui pourront vous vendre une copie papier ou sur disquette. 


\title{
RÉSUMÉ
}

Les critiques féministes ont au moins autant tardé que l'ensemble du milieu universitaire à reconnaître la légitimité de la communication électronique de travaux critiques. Cependant, on trouve chez les féministes issues du milieu des lettres et des arts une plus grande sensibilité à la philosophie, si ce n'est toujours au médium, des possibilités ouvertes par l'informatique. Le potentiel pour le développement d'une critique féministe hypertextuelle d'avant-garde est étudiée à la lumière de la mise en scène de la réalité virtuelle que propose Nicole Brossard dans son roman Baroque d'aube et du travail de l'artiste Catherine Richards intitulé The Virtual Body and Curiosity Cabinet, at the End of the Millennium.

\begin{abstract}
Feminist critics have been as slow to take up the tools of electronic scholarship as the academy has been at recognizing on-line criticism as a legitimate mode of investigation. Canadian experimental feminist authors and artists, however, are proving more likely to embrace the philosophy, if not necessarily the medium, of electronic possibilities. The potential for cutting edge hypertext feminist scholarship is examined through an examination of Nicole Brossard's use of Virtual Reality as a feminist discourse in her novel Baroque at Dawn (Baroque d'aube) and Catherine Richards' body-based, real time art explorations in her Virtual Reality installation pieces entitled The Virtual Body and Curiosity Cabinet, at the End of the Millennium.
\end{abstract}


In 1989, the year that virtual reality was born, MacUser magazine published an article which proclaimed that:

the ultimate goal of computer technology is to make the computer disappear, that the technology should be so transparent, so invisible to the user, that for practical purposes the computer does not exist. In its perfect form, the computer and its application stand outside data content so that the user may be completely absorbed in the subject matter (qtd, Ulmer n.p.)

The rhetoric surrounding virtual reality, on the other hand, argues not for the disappearance of technology, but for a disappearance of the body in favour of existence as a state of pure information. Katherine Hayles has pointed out that the body is both informational and material object (6) and that it is only "when one duality is chosen over another-when the body is seen only as information - that its erasure seems possible" (6). This elision of the body nullifies the spiritual component of ourselves and precludes any notions of psychological transcendence that should be possible in physical experiences, particularly experiences like the creative act, art and lovemaking. "[D]isembodied theorizing" (Greco) denies both consciousness and the sensory input that is integral to our navigation of the world: that being the proprioceptive sense, our physical sense of our body boundaries.

Marshall McLuhan called media 'the extensions of man.' What he foresaw as a discursive revolution is difficult to articulate because it is rooted in the language of the senses; it is what McLuhan called an "uttering [or] (outering) of all our senses at once" (McLuhan 83). He saw the sensory realm as informing all of our interactions with the world and with language itself, and it is language which mediates our proprioceptive awareness of the world. Computers, he said, are extra-linguistic and "point...the way to an extension of the process of consciousness itself, on a world scale, and without any verbalization whatever. Such a state of collective awareness may have been the preverbal condition of men" (McLuhan 83). And of women. /pp. 5-6/ 
As the body gets erased in discussions of technology, so do technological interfaces by users. These interfaces are, in essence, doors through which we enter to experience the "alternate universe(s)...our subjectivities can inhabit" (Hayles 1). Both virtual reality and hypertext environments overcome their own frames because they are immersive mediums and, since they exist as both literal and metaphorical realms, they affect us on a sensory level as extensions of the body. The mythopoetic nature of virtual reality (the reality of virtual reality has yet to catch up with the cultural mythology) is most often touted as a means of achieving transcendence through disembodiment, that is to say through some sort of uploading of the consciousness into an electronic or siliconbased form. Katherine Hayles, Margaret Morse and Diana Gromala have argued that virtual reality is more truly a form of reembodiment, a way of engendering a new awareness of our proprioceptive sense of the world. For critics, the combined mediums of virtual reality and hypertext offer a new opportunity for creating an embodied feminist online criticism that works with proprioceptive destabilization to map and to relocate ourselves in the discursive and material worlds.

These issues surrounding the senses and the body are topics that Nicole Brossard and Catherine Richards are examining with electronic technologies in their art. Catherine Richards undertook the first virtual reality experiment in Canada in 1991 at the Banff Centre for the Arts. Richards was eager to explore virtual reality as "a feminized technological environment" (Richards 259) and so she set out to "redesign subjectivity" (258) within that medium; her goal was to examine metaphorical links between what have traditionally been defined as female traits with the masculine nature and origins of the technological world (258). As an interactive medium, virtual reality is concerned with mapping behaviours and with "structuring and restructuring complex and shifting relationships" (259); this, combined with the virtual and literal blurring of boundaries, bodies and identities, is rooted in a networked world of connections (259). Richards found the possibility of wedding female subjectivity with military technology (where virtual reality has its origins) a /pp. 6-7/ 
fascinating premise and she has undertaken body-based, real time art explorations in her virtual reality installation entitled Curiosity Cabinet at the End of the Millennium, and in its companion piece Charged Hearts. This latter work is available on the web $<\mathrm{http}: / /$ www.charged-hearts.net/>.

In a similar vein, in 1995 Québécoise author Nicole Brossard published a novel called Baroque d'aube (Baroque at Dawn) that uses virtual reality as a female discourse of subjectivity. Brossard explicitly interconnects virtual reality with other forms of immersive feminist discourse, in particular jouissance or female desire, and the creative act itself. Both Brossard and Richards are interested in immersive environments and in the body as a threshold of sensory experience. It is not surprising that they have turned to virtual reality as a medium of expression in their concern with feminist issues, for, the ultimate immersive environment is a quintessentially female one: the womb.

Margaret Morse calls virtual environments: "liminal spaces, sacred places of social and personal transformation..., neither imaginary nor real, ...[they are] a subjunctive realm of externalized imagination where events happen in effect but not [in actuality]" (180). As an abstract form or a "structure of what does not yet exist" (Joyce 235) as Michael Joyce describes it, hypertext could also be said to be both virtual and liminal. One of these possible hypertextual structures is making its presence felt in the fact that hypertext, as a primarily textual medium, and virtual reality, as a primarily visual medium, are beginning to "blur together" (Bukatman). This blurring poses an invitation to actively unite the two to create a potentially revolutionary form for feminist criticism. Marshall McLuhan said that "The hybrid or meeting of two media is a moment of truth and revelation from which a new form is born. ...the meeting of two media is a moment of freedom and release from the ordinary trance and numbness imposed by them on our senses" (McLuhan 63). This new hybrid of hypertext and virtual reality languages like VRML (Virtual Reality Modeling Language) offers a critical potential for troubling the proprioceptive boundaries of traditional scholarship. This electronic form might /pp. 7-8/ dislodge 
us from our state of numbness and give us a new language with which to gesture towards the increasingly visual forms of contemporary art and literature.

Feminist critics have been slow to move into the arena of electronic scholarship. The reasons for this are legion, but seem to be bred of a scepticism of technological boy toys as much as a lack of access and expertise. This hesitation runs the risk of leaving feminist critics out of the game in the next millennium and we must acknowledge that literature in the 90's is no longer just the book. Hypertext is a mode of thought and a language ripe with potential for speaking a new feminist critical voice. The essence of hypertext is that it does what we cannot do in books, what we cannot do on the page. We cannot speak about it, for hypertext's function - the dynamic link - is wonderfully 'unspeakable.' The reason for this creation of a multi-linear form is threefold: it mimics the associational nature of thought or a polyvocalic space; it enacts simultaneous conversation; and it is comprised of embodied spaces that exist concurrently in time. Through the reader's act of choosing what a hypertext is and will become, hypertext becomes "embodied" by what are otherwise invisible choices in reading (Joyce 235). Blending hypertext with virtual reality in a critical space would open the possibilities for moving out of a dynamic two-dimensional critical space into an interactive three-dimensional one. Interactivity is not, however, the same thing as agency. Janet Murray argues that agency is born, not of interactivity as such, but through the act of spatial navigation within a text or an environment (Murray 128-129). In interactive environments, we construct the text as we read with our choices forming the contours of the space of our reading. A form of criticism that embodies agency as a native mode is essential to exploring feminist issues in women's art.

It is these principles that feminist critics require to discuss the effects artists like Brossard and Richards are realizing in their works. They are exploring possibilities for re-embodiment and sensuality in a transformative environment where space joins bodily sensations with navigation in real time. This is a method that a new hybrid electronic medium might apply to critical forms. /pp. 8-9/ 
There are problems in trying to talk about what is possible in fluid structures. As Isadora Duncan once said, "If I could explain it, I wouldn't have to dance it" (qtd, McDaid 455), but I will try to sketch out some of the possibilities here.

Brossard and Richards both use virtual reality as a feminine language, incorporating space and time into language simultaneously. In their work, polyvocality is key. Their works demand of a reader or a participant the abilities to inhabit alternate identities, to speak in many voices, and to make the jumps required by associational logic. There is no hierarchy in their virtual works, no authority because they speak the language of sensation as a primary voice through privileging the subjectivity of the interactor. This is the language of Julia Kristeva's semiotic chora, where the aspects of the semiotic concerned with expression, representation, gesture, sound and pattern are non-verbal. This is the unspeakable that our words exist in opposition to; the chora is a place that we can only ever know of, not know. This is what Kristeva found in the Derridean "virgin place," where the chora "is absolutely blank, everything that is printed on it is automatically effaced. It remains foreign to the imprint it receives... Everything inscribed in it erases itself immediately, while remaining in it. It is thus an impossible surface - it is not even a surface, because it has no depth" (Derrida, qtd in Ulmer, 1994, 65). The chora is clearly virtual and like immersive spaces it impresses itself on our bodies. Because the chora is analogous only to vocal or kinetic rhythms, it is also a fluid representation of the subconscious self and the body. Brossard and Richards link the changing depths of subjecthood and body to language through VR, and make these fluid boundaries real. These virtualities impress themselves on us in our subjective experience of their art.

Brossard's Baroque d'aube uses virtual reality to speak and to ultimately demonstrate its limitations in writing the body. The novel is the story of writer Cybil Noland who agrees to a creative project which requires her to experience the sea through virtual reality technology. Her journey inward into the fluid, creative process progresses through three immersive states, each /pp. 9-10/ of which 
explore feminine language: they are immersion in desire, immersion in the creative act and immersion in recollection, translation and revisioning. Like McLuhan's preverbal man, these feminist discourses are pre- or extra-linguistic and they are the sites where bodily sensation is privileged and speaks. Her fiction creates a space of collective individuality, an immersive space where the blurring of boundaries between individuals is free to happen and where "des trous dans la langue qui ne sont pas de silence" (233) ["the voids in language that are not from silence" (229)] can be articulated. In Baroque d'aube, this fact communicates a sense of the wondrous and is visited in the presencing required in the acts of love, of reading and of writing. The total experiences of lesbian lovemaking, immersion in the page or the creative act, argues Brossard, heighten and overwhelm all of the senses, thereby engendering corporeality of thought. Brossard privileges "l'intelligence des sens" (175) ["the intelligence of the senses" (171)] in comprehending "des paysages que seuls les yeux de lecture parvenaient à saisir" (75) ["landscapes visible only to reading eyes" (67)]. The novel is a virtual experience and immersive environments in Brossard's fictional world are juxtaposed with virtual reality to articulate feminist discourse and lesbian experience.

Catherine Richards, on the other hand, uses the immersion technology of VR to remap the body through manipulating the proprioceptive sense in two installations, Curiosity Cabinet at the End of the Millennium and Charged Hearts. VR literally overwhelms the subject by using bodily illusions and sensations to articulate the intervention of psychology in participants' perception of their bodies. Richards' works make her players believe that their body boundaries have changed. Seeing "the body as a crossroads where the psychological, material and virtual intersect" (Hayles 23), she makes the participant become the unique and particular subject of her art. As a result, each player's experience of the installation is intensely personal and transformative. The subject emerges changed; witness, for example, the wail of one visitor documented in Richards' film Spectral Bodies when after the experience the woman cries out, "Can you put me back [the way I was]?" (qtd, Hayles 26). /pp. 10-11/ 
Curiosity Cabinet is a large wood-panelled chamber that the visitor or interactor enters to participate in the experience. Richards juxtaposes nineteenth century technology - in this case, a "Faraday cage, a sort of antechamber protected from surrounding magnetic waves, whose purpose here is to 'unplug' the viewer enclosed within" (Gagnon) - against modern day viewers' expectations of a virtual reality like experience. The Curiosity Cabinet has a companion piece called Charged Hearts which 'plugs the viewer back in' (Gagnon) by allowing the participant to hold large glass, heart-shaped objects contained in bell jars - that are phosphorescently reactive to touch. Inspired by "early electrical technologies and devices...associated with plasma, the aurora borealis, and the cathode-ray tube" (Gagnon), Charged Hearts undoes the effects of the Curiosity Cabinet and reconnects the participant to her own body. Whether viewers take the throbbing glass objects in hand or 'plug themselves in' at a distance "by choos[ing] a heart, [and] playing virtually through the internet," the interactors are incorporated into the system, becoming "servomechanisms" (Gagnon). The demonstration of the online version of Charged Hearts that Richards gave in Banff last year had three tortured hearts named Edgar, Catherine and Heathcliff. Edgar persisted in 'feeling poorly' and fleeing Heathcliff, Catherine pursued Edgar and Heathcliff pursued Catherine. The three hearts were interconnected and any one was in danger of suffering a heart attack if overstimulated. The most common outcome of the scenario has Catherine end up in a coma. Through these technological interventions, Richards makes explicit the electromagnetic networking properties of our own bodies and emphasizes that cyberspace is precisely the same kind of embodied phenomena (Gagnon).

Immersive environments, like the painted cave, the sweat lodge, the medieval cathedral, Star Trek's holodeck and virtual reality, are by definition "psychological thresholds" (Hovagimyan). Abstract spaces are sites of transformation and transcendence where the subject returns altered by the symbolic experience. This type of "shift in consciousness" is generally the realm of religious ritual, but it is also the realm of art (Hovagimyan). The power of /pp. 11-12/ 
immersive spaces in modern experience - be they contained within the cinema, fiction or virtual reality-persists in their symbolic value of revelatory power. Immersion is a boundary state and the liminal is irreducible to subject and object: it alters consciousness by its very nature. Immersion is a process, an experience of an art form, and its abstract nature is therefore difficult to articulate. Virtual reality embodies its own poetics: "a spectator...enters a charged space-inbetween, taking on an itinerary, a role in a set in which images move through different ontological levels with each shift in dimension, in a kinaesthetic art, a body art, an image art that is rather an embodied conceptual art" (Morse 167). This experience falls within the abstract realm of the unspeakable, that is to say it exists outside of language. While Scott Bukatman argues that VR eliminates language, Margaret Morse says that entering a virtual environment is "as if one were immersed in language itself or as if the symbols on a map were virtually embodied as landscape" (Morse 181). In the same way, Brossard sees the consumption of words and meaning as a physical and sensory experience:

Tous les mots avaient un sens, il suffisait de les avaler, de les respirer, de les sucer, mâcher et aspirer avec conviction. Mais lorsque venait le temps de construire une phrase ou de s'installer dans le temps des verbes pour y vivre et s'émouvoir, alors les mots filaient comme une maille dans un bas de femme ou, chaos sombre, venaient s'interposer entre la réalité et soi (109).

[All the words had meaning and all she had to do was take a bite of them or breathe them, then suck chew and aspirate them with conviction. But when it came time to build a sentence or move into verb tenses in order to live and feel in them, the words would bolt like a run in a woman's stocking, or come and stand in gloomy chaos between her and reality (101).]

This is the immersive environment of language and creation itself, and in the novel Cybil Noland's VR experiences naturally end in a virtual birth. However, this does not mark the birth of a new age or even a new beginning. Brossard is critical of /pp. 12-13/ virtual 
reality as a form of disconnected sensation. Memory for Brossard is grounded in a utopian conjunction of past, present and future, and virtual reality is too disconnected from the real for Cybil Noland. She finds it contains 'too much presence' and that the main symbolique (the data glove that she navigates with in this environment) in no way fosters a form of embodied connection. This is a world that has been created and shaped by patriarchal programmers and, as such, it has too little materiality or history, and too much Oedipal complex (witness, for example, the brothers Demers and their bedroom fantasy - enacted in virtual space surrounding their mother.)

Keeping Brossard's point in mind, these new technologies offer possibilities for new forms of embodiment if we use material perspectives and feminist thinking to find ways of speaking in-thefeminine in the new technological realms. Brossard posits sibylline ecstasy and prophecy as counterpoints to a counterfeit patriarchal form of immersion that celebrates fantasy and ultimately rejects real time sensation. Cybil's perspective in Baroque d'aube, therefore, is out of necessity an embodied threshold experience. In the moment when the voice sounds out of the darkness at sea, a window is opened by the sibyl's voice that allows Cybil a whole new kind of perception; the seer promises a new kind of artistic vision that will transform Cybil's writing into a sibyl's work - prophetic ecstasy - in the future. What Brossard and Cybil Noland (with their split subjectivities and multiple speaking 'situations' in the text) are seeking to create is what we should emulate in our criticism: a transformative, 'sensational' environment where embodied navigation is possible in the real time of a sensory, critical realm. I would argue that the virtual spaces of VR and hypertext function as languages or, more correctly, as discourses of sensation. Hypertext and virtual reality can draw in all of the senses (except smell) and give the interactor a different kind of embodiment for the practice of criticism. The disjuncture of images, sounds and words makes all of the elements of a hypertext function like a language, but an embodied language like the hysteric's body-grammar that has no simple representation in speech. This is synaesthesia/pp. 13-14/ made flesh 
in the realm of the semiotic chora. Describing the experience of virtual reality, Brossard says:

Le corps, vous verrez, le corps c'est comme si le corps réorganisait les pensées afin qu'elles s'imbriquent naturellement les unes dans les autres. Le corps devient pure sensation avec des gros plans de bien-être qui défilent comme des bancs de poissons magiques. Inutile de penser à l'abîme. Il entre en nous, somme d'émotions impossible à chiffrer. L'important, c'est la profondeur. Descendre (167).

[it's as if the body reorganized one's thoughts so they overlap in a natural way. The body becomes pure sensation, with close-ups of well-being coming by like schools of magical fish. No point thinking about the abyss. It simply enters us, a sum of emotions impossible to enumerate. What's important is the depth. Descending (163).]

Using our bodies to reorganize our thoughts as critics, we need to reinsert our proprioceptive sense and our material awareness of the world back into our scholarship. Critical nomadism in the fluid, immersive, interactive, interdisciplinary forms of hypertext and VRML offers multi-linear possibilities for erasing binary-based, authoritarian theorizing. Like in Richards' installations, we need to be aware of "the psychological (re)mapping of our bodies" (qtd, Hayles 22) that new technologies are enacting on us and we need to use these new sensations to understand ourselves, our bodies and our art.

Both Richards and Brossard see their role as one of "inventing new images for the body" and articulating the "net of interconnections" inherent in female subjectivity (Richards 258). This highlights the feeling of being plugged in. And since "subjunctive identities are grounded in narrational journeys" (Morse 201), we as critics must plug ourselves back into the territories of the unspeakable that our artists are exploring by using the same narrational and navigational tools. /pp. 14-15/ 
The problem remains in finding a way to speak about embodied experience. Margaret Morse has written at length on the virtualities of video installation and VR, which she calls "the most complex art form in contemporary culture" (Morse 157). The fact that these experiences are events makes it particularly difficult to document the essence of immersive forms. Morse says: "While an installation can be diagrammed, photographed, videotaped, or described in language, its crucial element is ultimately missing from any such two-dimensional construction, that is, "the space-inbetween,' or the actual construction of a passage for bodies or figures in space and time" (157).

As critics, this ultimately leaves us in a position where we must find three-dimensional ways of speaking to capture the amniotic essence of feminist work. We need to be able to articulate this sense of dislocation in space, time and language. Donna Haraway's utopic and revolutionary pleasure in the cyborg's blurring of boundaries is too metaphorical, is more manifesto than contextualized strategy; hypertext and VR offer us the potential for incorporating material, interdisciplinary sensation into our criticism.

The disorienting intersection of text and image in our contemporary world is a new language. It is what Marshall McLuhan called "the next logical step": "not to translate, but to by-pass languages" to arrive at a state of "weightlessness" and "speechlessness" (84). This is Isadora's dance once again. This is what Umberto Eco calls 'work in movement' (often quoted in reference to hypertext by Michael Joyce). Hypertext theorist and novelist Carolyn Guyer calls the modern sense of creative dislocation "being split among places" or a "buzz-daze" state (Guyer). This is a threshold or liminal condition that makes the creative act possible both in our art and in our criticism. Hypertext and virtual reality draw the reader in as a key element in the text through connections in space and, because hypertext and VR recreate the buzz-daze state on more intimate terms, they invite a weightless or nomadic association rather than a homeless, disconnected one. /pp. 15-16/ 
In her book Nomadic Subjects, cyberfeminist theorist Rosi Braidotti speaks of female identity as a matrix of interconnected points based not on fixity but on contingency. For her, the postmodern feminist consciousness is rooted in mobility, and mobility of all kinds: moving across linguistic and national boundaries, moving out of traditional roles, becoming interdisciplinary, becoming deterritorialized. At the same time, Braidotti does not see nomadic subjectivity as aimless drifting, but as being sympathetic to Donna Haraway's "situated knowledges." Braidotti states:

As Haraway rightly puts it: you must be located somewhere in order to make statements of general value. Nomadism, therefore, is not fluidity without borders but rather an acute awareness of the nonfixity of boundaries. It is the intense desire to go on trespassing, transgressing. As a figuration of contemporary subjectivity, therefore, the nomad is a postmetaphysical, intensive, multiple entity, functioning in a net of interconnections. S/he cannot be reduced to a linear, teleological form of subjectivity but is rather the site of multiple connections. S/he is embodied, and therefore cultural; as an artifact, s/he is a technological compound of human and posthuman; s/he is complex, endowed with multiple capabilities for interconnectedness (Braidotti 36).

By blending art with literary hypertext and visual VR, we can show how the unspeakable elements of subjectivity operate in the "amniotic ocean" (Morse 185) of the virtual worlds of feminist artists. We can respond instead of critiquing and speak with these forms instead of about them. As embodied critics, we need to apply our critical tools like brushes on a canvas to explore the colours and sensations of contemporary art through a critical proprioceptive destabilization and a literalization of abstract spaces and discourses. We must incorporate vision and gesture and the reader into our immersive and interactive critical environments to create transformative words, allowing us to reincorporate psychology and French feminist theory with 1990's technology. This conjunction of the most embodied languaging we have ever seen with /pp. 16-17/ 
Kristeva's most abstract offers revolutionary possibilities. As critics in a visual age, we can draw from the sensations that exist outside of language by using visuals, links, ruptures and gaps to tap emotional veins.

\section{Carolyn Guertin Department of French University of Alberta}

Presented in a slightly altered form on 28 May 1998 at the HSSFC Congress for ACCUTE and the Consortium for Computing in the Humanities, University of Ottawa.

Braidotti, Rosi. Nomadic Subjects: Embodiment and Sexual Difference in Contemporary Feminist Theory. New York: Columbia UP, 1994.

Brossard, Nicole. Baroque d'aube. Montréal: L'Hexagone, 1995.

---. Baroque at Dawn.. Patricia Claxton, Trans. Toronto: McClelland and Stewart, 1997.

Bukatman, Scott. "Virtual Textuality." On-line. URL: $<\mathrm{http}: / /$ jefferson.village.virginia.edu/ jmu $2 \mathrm{~m} /$ bukatman.html>

Gagnon, Jean. Catherine Richards' Charged Hearts. Show catalogue. Ottawa: National Gallery, 1997.

Greco, Diane. "Hypertext with Consequences: Recovering A Politics of Hypertext." Online. URL: <http://www.cs.unc.ed/ barman/HT96/P79/ht96.html>

Gromala, Diana. "Pain and Subjectivity in Virtual Reality." Clicking In: Hot Links To A Digital Culture. Ed. Lynn Hershman Leeson. Seattle: Bay Press, 1996. 222-237.

Guyer, Carolyn. "Buzz-Daze Jazz and the Quotidian Stream." Online. URL:

/pp. 17-18/ $<\mathrm{http} / /$ mothermillennia.org/Carolyn/Buzz_Daze.html> 
Hayles, N. Katherine. "Embodied Virtuality: Or How to Put Bodies Back into the Picture." Immersed in Technology: Art and Virtual Environments. Cambridge and London: MIT, 1996. 1-28.

Heim, Michael. The Metaphysics of Virtual Reality. New York and Oxford: Oxford UP, 1993.

Hovagimyan, G.H. "Notes on Immersion." Online. URL: $<$ http://www.millersv.edu/ resound/*volliss2/ immersion.html>.

Joyce, Michael. Of Two Minds: Hypertext Pedagogy and Poetics. Ann Arbor: U of Michigan P, 1995.

McDaig, John. "Breaking Frames: Hyper-Mass Media." Hypertext/Hypermedia Handbook. Emily Berk and Joseph Devlin, Eds. New York: McGraw-Hill, 1991. 445-458.

McLuhan, Marshall. Understanding Media: The Extensions of Man. New York: Signet, 1964.

Morse, Margaret. Virtualities: Television, Media Art and Cyberculture. Bloomington: Indiana UP, 1998.

Murray, Janet H. Hamlet on the Holodeck: The Future of Narrative in Cyberspace. Cambridge, Mass.: MIT, 1997.

Richards, Catherine. Curiosity Cabinet, at the End of the Millennium. Installation piece. 1995.

---. Charged Hearts. Installation piece/online site. Online. URL: <http://www.charged-hearts.net/>, 1997.

---. "Fungal Intimacy: The Cyborg in Feminism and Media Art." Clicking In: Hot Links To A Digital Culture. Ed. Lynn Hershman Leeson. Seattle: Bay Press, 1996. 258-263.

Ulmer, Gregory. "Grammatology Hypermedia." Postmodern Culture.

Online. URL: <http://www.iath.virginia.edu/pmc/textonly/issue.191/ulmer.191>n.p.

Ulmer, Gregory L. Heuretics: The Logic of Invention. Baltimore and London: Johns Hopkins UP, 1994.

/p. 18/ 